\title{
Culture and Economic Security in Africa: Analysis and Implications of Indigenous Knowledge Systems
}

\author{
Wilson E. Herbert \\ Dept. of Banking and Finance, Faculty of Management Sciences, Federal University, Otuoke, Bayelsa State, \\ Nigeria
}

\begin{abstract}
Throughout history, great nations have been built and great developmental strides attained, not by inchoate policies or untailored measures, but by well-articulated systematic policies of sustained development. For Africa, development policies and programmes must be circumscribed by a clear understanding of the crucial role of the forces of cultural and economic security on the development process. Given the giant leap in economic, political and social development by other developing continents vis-à-vis Africa, it has become imperative to ponder these questions: Do African cultures encumber or foster Africa's economic development? Is Africa's leadership challenge rooted in her cultural heritage? Despite huge natural resources and potentials, the crisis of Africa's poverty and underdevelopment juxtaposing corrupt and inept national leadership warrants a reassessment of the trajectories of Africa's development. Indigenous peoples' cultures and their knowledge systems have had a determinative effect on the lives, socioeconomic development trajectory and pace of development of Africans. Yet, these cultures and their knowledge systems have been largely misunderstood, incompletely developed or even ignored by conventional models of economic development. Understanding the crucial role of the dynamics of culture and security in economic development of nation states is important, especially given global commitment to democracy, human rights and pluralism (political, religious and cultural). This paper identifies the cultural challenges that cause the success or failure of national development in Africa. It prescribes the synthesis and remodelling of the apparatuses of cultural and economic security in the bid to foster economic development in the region.
\end{abstract}

Keywords: Africa, Culture, Cultural Infrastructure, Cultural Security, Economic Security, Economic development, Indigenous knowledge systems, Nigeria

DOI: $10.7176 / \mathrm{JCSD} / 60-05$

Publication date: June $30^{\text {th }} 2020$

\section{Introduction}

Every society has a culture, which defines and carries its values. A society's culture influences the thoughts, feelings and actions of her people. Africa's cultural security encompasses Africa's invaluable human qualities and traditions which are rooted in her cultural heritage. However, colonisation and neo-colonisation in the face of western civilization have robbed the continent of her cultural security and, consequentially, economic security. There is a connection between Africa's economic insecurity and the neglect of African cultural values, embedded in her identity and security as Africans. Africa's rich cultural heritage defines and underpins Africa's civilization. That civilization began in Africa, precisely in Egypt, is scarcely newsworthy in this era of globalization and information and communications technology (ICT), especially Internet. Traditional African culture is imbued with warmth, hospitality and sense of community; built on optimism and resilience, even in the face of adversity; thrives on communal effort; anchored on tribal politics, leadership and patronage; largely agrarian or bucolic; and secured on self-determination (Herbert, 2012). The relevance, universal applicability and bounded rationality of indigenous peoples' cultures and their respective knowledge systems in explaining Africa's lagged economic development and other multidimensional social phenomena are incompletely developed in models of socioeconomic and political development. To be sure, both the historicity and trajectory of Africa's economic development or underdevelopment have differential relationships with their environment or country experience or origin. I contend that the culture and geography of economic development and economic behaviours (that is, their origin, pattern and significance thereof) differ with a country's level of development, qua civilization. Put differently, the capacity of African countries to leverage their indigenous (traditional) knowledge systems (IKS) in support of socioeconomic and political developments has varied considerably. Yet, indigenous knowledge is considered "the social capital of the poor, their main asset to invest in the struggle for survival, to produce food, to provide for shelter and to achieve control of their own lives" (Senanayake, 2006).

The acculturation of western values and practices and the intrusion of foreign technologies and development concepts, facilitated by globalization and advances in ICT have led to the disappearance indigenous knowledge. The impact of differential western acculturation is prominent in the type of education, legal system, economic and political system and societal value, consistent with the country of colonial administration. However, just as the distribution of culture in the world reflects the distribution of power, so does its disappearance or attenuation signify loss of influence (Herbert, 2012). The recession of colonial administrations following political 
independence saw immediate erosion of colonial culture. The indigenisation of local and national cultures progressively swept away colonial hegemony with their cultures and civilizations, and in their place saw a rapid reassertion of indigenous mores, beliefs, languages, and institutions. The rapid disappearance of Western societies and civilizations and the growing power of indigenous cultures produced at worst powerful anti-Western civilizations, or gradual dismantling of the apparatuses of Western societies at best. Ancient kingdoms with historically rooted traditions became the command power and new order of village or rural community life. But the gains of colonial civilization and cultures were lost and abandoned to the ignominy of ruthless, visionless and corrupt independent African leaders.

The interest of this paper is on the important role of the amalgam of cultural security and economic security on the development process of Africa. In one dimension, the issue can be put differently thus: Do African cultures encumber or foster Africa's economic development? Understanding the crucial role of the interplay of cultural dynamics with economic development of nation states is important, especially in a capitalist economy. Further, understanding the complex systems of national security and why the economy is a part of the equation is crucial. Globalisation has made the world a small place, and world peace and security may depend upon our ability to understand and articulate these issues - and, in particular, to recognise the importance of the dynamics of cultural and economic security of national, regional and continental power.

There is a school of thought that holds the view that activities and conditions within the economy fundamentally influence the operations of the state (see, Block, 1977; Szymanski, 1978; Crouch, 1979; and Herbert, 2011). In a pluralist capitalist society, the configuration of economic activities is on the basis of private ownership of the society's productive resources, with the production, distribution, and consumption of wealth governed by social relations centred on the dynamics of the market and culture of the people. Culture is a catalyst in social cohesion and stability of society. Social stability in the broadest sense is dependent on a healthy economy. This paper identifies the cultural challenges that cause the success or failure of national development. Much of the success or failure resonates with the government of the day, as represented by the country's leader. The emphasis of national development targets a redefinition of the role and behaviour of a leader in the governance and transformation process of the society. From this perspective, the critical question is: Is it possible to evolve, integrate and manage cultural changes that foster economic development?

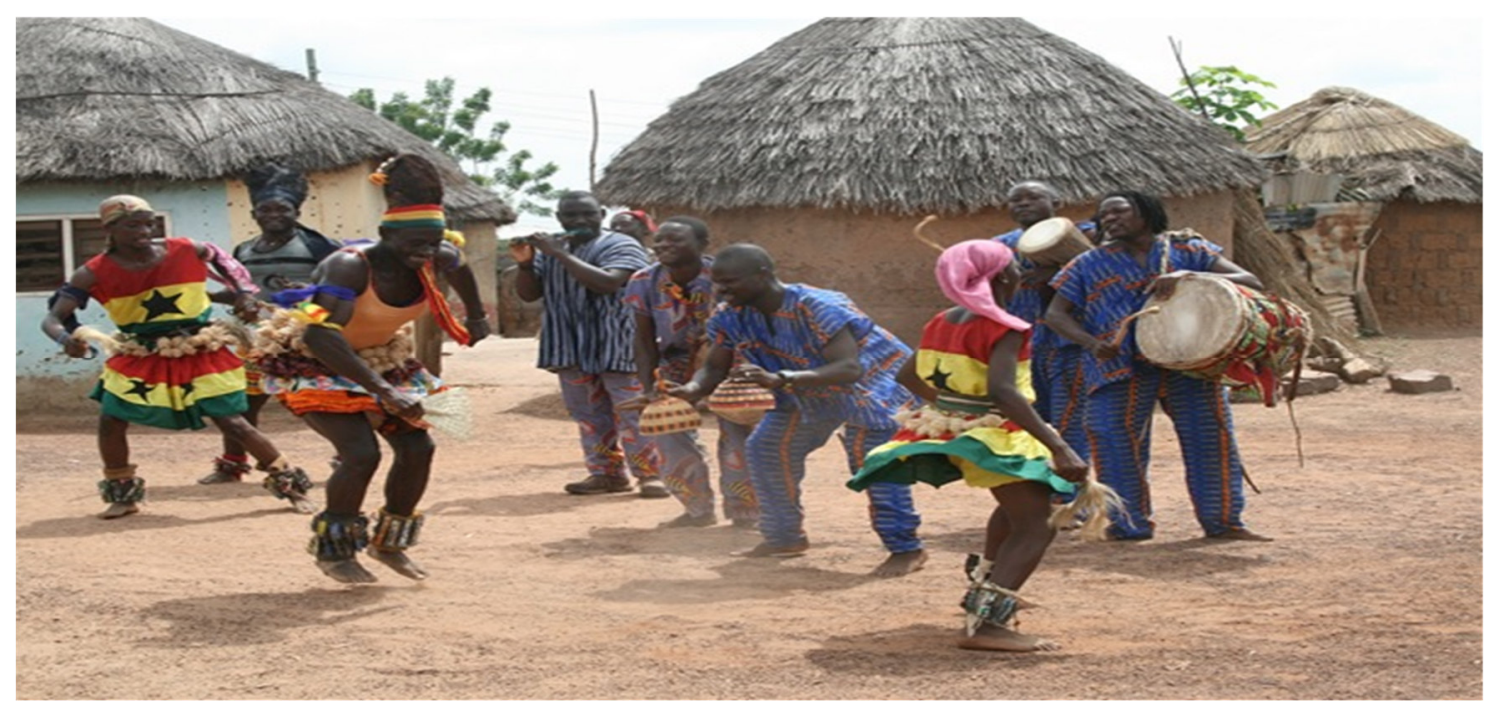

Figure 1. The Neglect of African cultural values is the source of Africa's economic security

Every society has a culture, which defines and carries its values. A society's culture influences the thoughts, feelings and actions of her people. Africa's cultural security encompasses Africa's invaluable human qualities and traditions which were endowed on us in our cultural heritage. However, colonisation and neo-colonisation in the face of western civilization have robbed the continent of her cultural security and, consequently, economic security. There is a connection between Africa's economic insecurity and the neglect of African cultural values which were embedded in our identity and security as Africans.

The theme of this paper seeks to evaluate culture and economic security issues and their national, regional or continental security implications. It derives from a growing concern about the failure or inadequacy of extant models and how these can be remodelled. The paper attempts to locate the interrelations between cultural security and economic security and the relevance and impact of indigenous (traditional) knowledge systems (IKS) on 
Africa's economic development. The aim is to enrich extant knowledge about the way African cultures frustrate or encumber Africa's economic development. Remodelling the options has become imperative in contemporary geopolitics, with the ubiquitous incursion of globalisation in the affairs of individuals, communities and nation states, and culture and economic security issues assuming more important and more international dimensions. These dimensions warrant a mandate for a deeper look at their role in economic development and growth.

It is helpful to provide on the onset some conceptual overview of economic and cultural security as a prelude to the special relevance of cultural and economic security in economic development. The consequences of economic insecurity can be gleaned from the factors that pose a threat to economic security. The global context of the relations between African cultures and Africa's socioeconomic development sets the stage for continental agendas in perspective and the policy options. Looking ahead provides the background to concluding remarks.

\subsection{Some Conceptualising}

Security (need to feel safe) joins with physiological needs for survival (need to stay alive and reproduce) to form the most fundamental and most pressing needs of humanity, under Maslow's Hierarchy of Needs (Maslow, 1943, 1954). These are followed by social needs (for love and belonging) and self-esteem needs (to feel worthy, respected and have status). The final and highest level of needs is self-actualisation needs (self-fulfilment and achievement). The underlying theme is that human beings are 'wanting' or 'craving' beings - in a steady state of wants. As they satisfy one need the next emerges on its own and demands satisfaction. The desire or hunger for more or better things in life culminates in the need for self-actualization which, by its very nature, cannot be fully satisfied and thus cannot generate more needs.

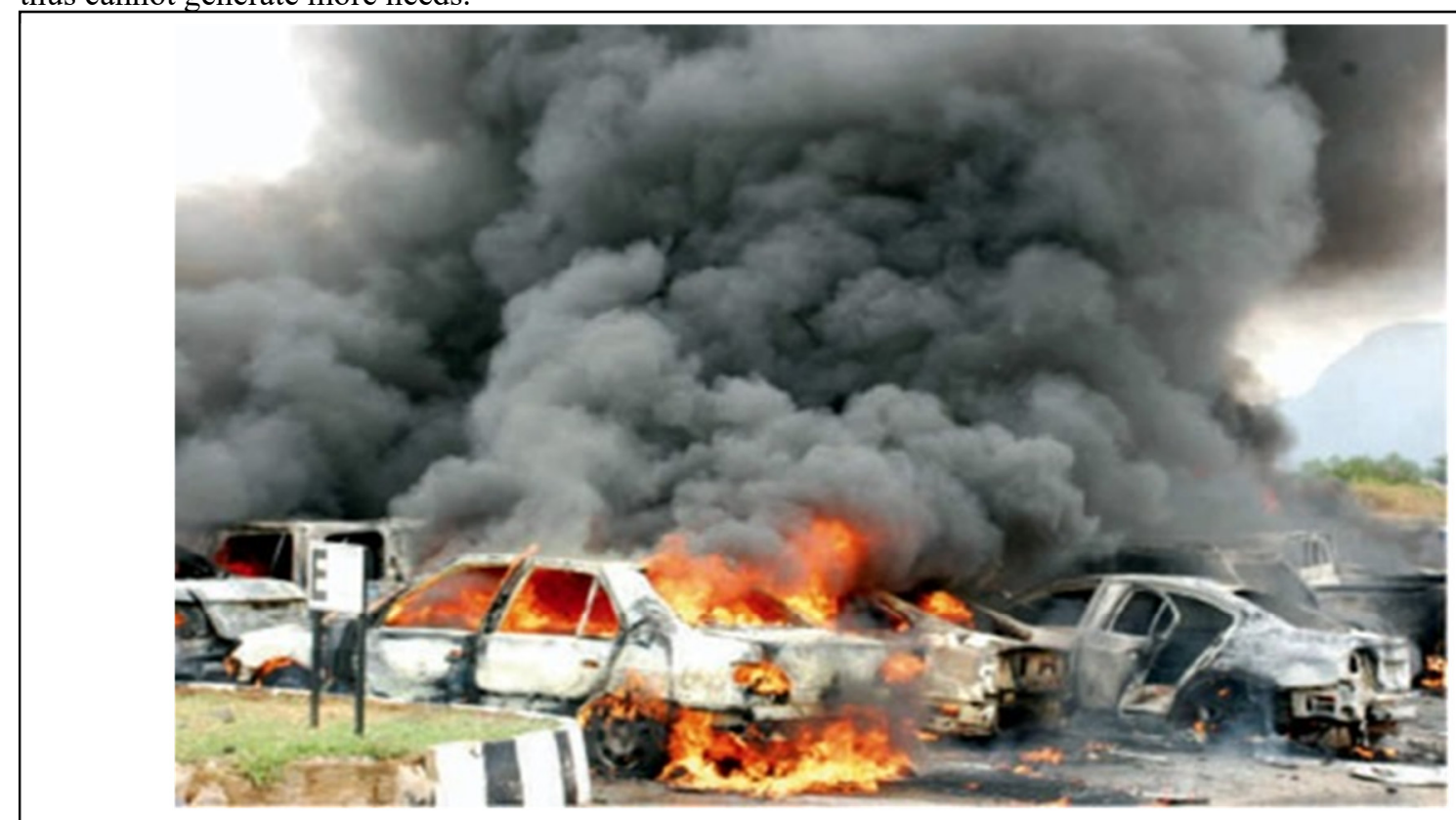

Figure 2. Face of Insecurity in Africa: The Bane of Africa’s Economic Development

The antecedent to Maslow's motivation theory of pecking order of human needs might have been the 1948 United Nations Charter on the "fundamental human rights, and dignity and worth of the human person" which require global commitment to promote "universal respect for, and observance of, human rights and fundamental freedoms for all without distinction as to race, sex, language, or religion". The adoption of the Universal Declaration (UN, 1948) is a significant international commemoration marked each year on 10 December, and is known as Human Rights Day or International Human Rights Day. The Universal Declaration is anchored on four freedom pillars: freedom of speech, freedom of religion, freedom from fear, and freedom from want, which were derivatives of the four basic war aims adopted by the Allies to guide the prosecution of World War II.

Security in all its ramifications is fundamental to, and coextensive with, development, wealth creation and wealth of nations. Once security needs are solved, they calm the frayed nerves of economic development and the various strains that pull a nation or a region apart. Therefore, cultural and economic insecurity provides a unique framework to explain the explosion of poverty, diseases, intractable ethnic militancy and religious tension, and terrorism, all tapping into the deep veins of insecurity and human desperation in Africa.

Economic security has preoccupied national governments and global institutions such as the United Nations for many years. However, its global resonance assumed greater proportion following the unexpected and severe 
dimensions of the economic shocks of the 1980s and the recent global meltdown of 2008-2009 which severely shook and threatened the foundation of extant social and political arrangements. Economic security, also known as financial security is the derivative condition of income or resource stability to support and sustain a given standard of living, both now and in the foreseeable future. Economic security encompasses continued solvency, predictability of future stream of cash flows, and employment or job security. In simple terms, to be economically secure is to have sufficient resources to cover one's daily needs or expenses.

In broader national, regional or geopolitical consideration, economic security has a much wider connotation than just financial security. Financial security is commonly associated with individual and family income or asset stability, including money management and savings. Economic security, on the other hand, has a wider connotation. It includes the wider effect of national production and productivity levels and monetary support for the unemployed and the elderly. Economic security implicates the competitive advantage of a nation. It is often used euphemistically to promote the safety, well-being, and self-sufficiency of children, adults, and families. Economic security is also used in the context of politics and international relations. Under this genre, it adumbrates a country's ability to follow its choice of policies to develop the national economy in the manner desired. In this connection, governments deploy economic security as a political tool to justify or underscore certain public policies, such as underwriting the country's diplomacy and development efforts or the imposition of tariffs or a ban on the importation of certain goods as part of a strategic impulse in promoting national security. In today's complex system of international trade, characterised by multi-lateral agreements, mutual inter-dependence and availability of natural resources, economic security may be as important a part of national security as military policy. The configuration of international settlements may include propositions for economic security as a key determinant of international relations. To be sure, threats to a country's economic security are in many respects construed as economic espionage, tantamount to acts of aggression or coerciveness by a foreign government with the aim of gaining unauthorised access to economic intelligence, such as proprietary information or technology, for economic advantage.

\subsection{Nature of Africa's Indigenous Knowledge Systems in Cultural Security}

Africa's indigenous knowledge systems, similar to other indigenous societies around the world, are traditionally applied in harmony with the natural and spiritual world (Lalonde, 1991). These traditional or cultural practices are resourcefully designed to resolve local challenges, including law and order, social or communal harmony, protect and maintain a sustainable utilization of commonly shared heritage as well as address ecological limitations (See also, Lalonde, 1991). Historically, indigenous peoples' cultures and their respective knowledge systems have had a determinative effect on the lives, socioeconomic development trajectory and pace of development of Africans. Yet, these cultures and their knowledge systems have been largely misunderstood, incompletely developed in or even ignored by conventional models of economic development or of firms and markets. This much has been echoed in the "Report of the World Commission on Environment and Development (WCED): Our Common Future", commonly referred to as United Nations Brundtland Commission, named after its chairman, Gro Harlem Brundtland. The Commission observed that "some traditional lifestyles are threatened with virtual extinction by insensitive development over which the indigenous people have no participation. Their traditional rights should be recognized and they should be given a more decisive voice in formulating policies about resource development in their areas" (Brundtland Commission, 1987). Fernández (1994) had equally noted that indigenous knowledge systems have long been undervalued.

The indigeneity of local knowledge - variously referred to as folk knowledge, people's knowledge, native wisdom or traditional science - resides in its singularity in cultural respects. Indigenous knowledge and its systems are both idiosyncratic and confined to a particular culture, community, tribe or society. In effect, indigenous knowledge is that which is unique, peculiar and confined to a particular culture, community or society. Understanding the cultural content of indigenous knowledge and systems has been important in facilitating the involvement of national and international agencies in sustainable development programmes and socialenhancement and protection programmes as well as development and security issues. Even life-saving 'mundane' programmes like providing social and medical services to indigenous people are circumscribed by cultural and religious considerations. Sustainable development programmes are broadly tailored towards expanding the real freedoms of citizens, especially those at the lowest rungs of the ladder. However, their implementation process involves narrow and rigid views of development that have cultural implications, including sociocultural diversity and gender-differentiated knowledge and skills. The centrality of freedom in the process of development in general obligates understanding and harnessing the nuances of local cultures because achieving development is fundamentally dependent on the free agency of people. Indigenous knowledge is generated and transmitted by communities or tribes through a systematic process from generation to generation, usually by word of mouth and cultural rituals, in an effort to cope with their own agroecological and socio-economic environments (Fernández, 1994). For all intents and purposes, indigenous knowledge has been acknowledged as the basis for agriculture, food preparation and conservation, health care, education, and a wide range of other activities that sustain a society 
and its environment in many parts of the world for many centuries (ibid.).

It is generally conceded (by researchers, NGOs and international humanitarian organisations) that if due recognition is not accorded to the powerful role of indigenous people and their indigenous knowledge systems, then development policies and programmes would be subject to hazards. Lalonde's (1991) observation is apt: "It is reasonable to assume that important global development assistance activities, including local participation, capacity building, and sustainable resource management can be enhanced in cost-effective programs and strategies which understand and work with indigenous knowledge and indigenous decision-making systems." Lalonde then calls for integration of indigenous knowledge with development planning techniques, and with the rich diversity and number of indigenous cultural groups throughout Africa, the continent is considered ideal for the integration of IKS into models of development.

\subsection{Towards a Conceptual Framework of Cultural Security}

The term 'cultural security' is not amenable to a precise definition. It is a compound terminology with a composite meaning, which depends on the notions of 'culture' and 'security'. From the perspective of culture, 'cultural security' refers to the preservation or protection of the heritage and values of a people or a nation (see Nemeth, 2013). From the security lens, the term designates the significance of culture to national, regional, or international security. Cultural security contextualises the evolving role of culture in politics, economics, and national and international security. However, different national contexts evoke different perceptions just as specific national contexts stir up specific perceptions. For example, in Australia, cultural security is used in the context of the aborigines with respect to how modernisation threatens to change their way of life (AHRC, 2011). In China, cultural security is used as a political tool to guard against the perceived negative influence of foreign culture, especially the influx of foreign pop music. In Africa, the term is used to express the concerns of African governments over the impact of globalisation and development on local traditions.

In the wake of globalisation, there has been a growing perception that the central and most discontent of the emerging global order is the conflict between groups from differing civilisations. For example, several initiatives of global bodies like the U.N., World Bank, IMF, and WTO have grassroots consequences for many societies, cultures and beliefs. Initiatives such as the Millennium Development Goals, poverty-reduction strategies, girl-child education, healthcare delivery campaigns (anti-malaria and AIDS awareness campaigns) have obvious implications for rural communities. The joining of unmet challenges of extreme poverty with these seemingly innocuous global initiatives not only challenges cultural orthodoxies of inner civilisations, but more importantly the ensuing 'clashes of civilisations' (Huntington, 2002) threaten national and global security. For example, in many parts of Africa, especially in the core Muslim communities, there has been a resentment towards polio immunization and other conventional healthcare practices based on religious precepts. This cultural or religious aversion to global best medicare practice is reprehensible or opprobrious, but it reflects the deep-rooted cultural resentment by a people held together by nothing more than religious belief or sentiment. Perhaps, this antipathy illustrates the ideological foundation of the Boko Haram sect against Western education and Western cultures even when the sect uses Western weaponry to prosecute its militarised agenda.

Thus, as globalisation and international development initiatives creep into the crevices of local communities and institutions, the resultant clash of civilisation impacts on the beliefs, practices and traditional values of the indigenous people and communities. The situation becomes more complex when cultural artefacts of a people or country become a subject of foreign protection, with the growing interest in the global market for antiquities and tribal art. In recent times, there has been international outcry over the sale of ancient tribal or indigenous artefacts that transcend current cultural property laws (See, Sally Johnson on CulturalSecurity.net.). Recently too, UNESCO has, under its World Heritage Sites, identified with the need to preserve cultural heritage across the world. When monuments on the World Heritage Sites are threatened by natural erosion, economic development, or militancy and insurgency, cultural security assumes a global significance.

The introduction of cultural security was informed by two major objectives. The first is to bring into mainstream economics literature an understanding of the important role indigenous and non-indigenous cultures, knowledge and experiences play in economic development, and to acknowledge that people's beliefs, experiences, and practices play a significant part in determining economic outcomes. This information framework will assist in developing new and improved strategies for Africa's economic development. Secondly, the longer-term goal of cultural and economic security is to draw the attention of African governments, business leaders, academics, NGOs and CSOs to the important role of cultural imperatives or dynamics of society's mores on the political, social and economic development of nation states. This is to raise their consciousness of the need to improve socioeconomic outcomes for Africa by developing African professionals with the capacity to provide culturally appropriate services. Cultural awareness and understanding and cultural safety and security are viewed as essential in improving economic outcomes for national and regional development. Raising the consciousness of the significance of indigenous cultures may enhance the delivery of social services, especially education and healthcare (See for example, Bessarab, 2000; Coffin, 2008; Drury, 2010). 


\section{Dimensionalising Cultural Security}

Cultural security is a broad concept that encompasses cultural safety, cultural sensitivity, and cultural awareness (see Coffin, 2007). Cultural safety refers to the condition in which people recognise their own culture, language, customs, attitudes, beliefs and preferred ways of doing things in their social and economic environment, workplace or public setting. Cultural sensitivity is associated with an evaluation and comparison of different attitudes and experiences, examining how personal experiences, attitudes and prejudices can influence the lives of other people, particularly in the socioeconomic setting. Cultural awareness is about learning about the culture of various communities, including the natives or aborigines. The overarching goal of cultural security is to improve indigenous people's access, experience and outcomes of mainstream services. Cultural security directly links understandings and actions. Policies and procedures create processes that are automatically applied from the time indigenous people first seek socioeconomic service, such as education and healthcare (ibid.). In essence, cultural safety encapsulates the relationships needed to foster cultural renewal and revitalisation in indigenous communities, while cultural security refers to the obligations of evolving policies and adopting practices which ensure that all interactions with indigenous communities adequately conform to or meet their cultural needs.

\subsection{Cultural Security and Security Culture}

Often, there is a mix-up in the usage of the terms "cultural security" and "security culture". Security culture refers to a set of customs, values, tenets shared by a community of people whose practices and/or activities threaten national or global stability. Note that it is not merely the membership of the group or sect that poses security challenge, even though that may be instrumental; rather, it is their behavioural pattern and obnoxious practices which actually or putatively violate or threaten the rights of other citizens and put them in danger. Because it is the natural responsibility of the state (government through its security agencies) to protect lives and property, any culture, tradition, belief or practice that threatens or has the potential to threaten regional, national or global security is bound to be viewed in reprehensible terms and resisted. In specific terms, the focus of security culture is to keep 'infiltrators' and other potentially-damaging parties out.

Writing under the Recent news references to "cultural security" (weblog CulturalSecurity.org), Sally Johnson, Eric Nemeth and others note that cultural security explores the political economy of art and the power of cultural heritage in diplomacy. They further observe that research, analysis, and creativity shape the space in which art and culture influence foreign policy and security. Thus, cultural security is about the interrelation of cultural property, diplomacy, and international security; and research in cultural security is an examination of this interrelation to define a framework for cultural intelligence.

\subsection{Threats to Economic Security and Consequences of Economic Insecurity}

Why does economic insecurity matter? Economic insecurity manifests in several forms. The following circumstances are important guides to individual or collective (national) economic insecurity: low or no earnings due to unemployment or loss of employment or a large unexpected cost, significant decline in income, sustained period of unemployment, significant loss of assets or resources, and large unexpected costs. Economic insecurity reduces living standards, exacerbates unemployment, increases anxiety and stress, and dislocates the economy. The growing level of ignorance and indifference aggravates economic insecurity by fuelling suspicion, ethnic prejudice and religious bigotry. The evidence of these is glaring in the North Eastern part of Nigeria, mainly, Adamawa, Borno, and Yobe States, following the unrelenting terrorist activities of the Boko Haram sect. Having a persistently low income or prolonged unemployment and/or being at risk of a significant decline in income can be stressful. Also, people on persistent low income tend to be unhappy just as unemployed people tend to experience bouts of unhappiness. This explains why social insurance provision is a key component of government's social responsibility in advanced economies. In these climes, most popular government social programs- social security, medicare, unemployment benefit or compensation - are viewed as economic security insurance rather than (welfare) redistribution. In Africa and many developing countries, social and economic security is rooted in nuclear and extended family setups. Parents and relatives naturally look up to their children or close relatives for social welfare and economic security support.

\section{Relations between Culture and Economic Development}

The new institutional economics has been preoccupied with the origins, incidence, and ramifications of economic transactions. A largely unexplored praxis is the relationship between African cultures and Africa's socioeconomic development. Putatively, how have African cultures contributed to or hampered Africa's socioeconomic development? Are African cultures an impediment to Africa's socioeconomic development? If so, dramatic social and cultural shifts may be warranted in identifying egalitarian market-driven industrialisation cultures that require attitudinal changes. There is unanimity with the proposition that economic development is a derivative of complex and important social and cultural imperatives. However, there is much less agreement on the attributes of these imperatives and how and why they have evolved to take on current economic development configuration. It is 
acknowledged that economic development is mainly to be understood as the product of a series of cultural innovations. History has shown that there is a cultural dimension to economic development, and vice versa. For example, the general concession that the existence of formal economic institutions, such as property rights, rule of law, and contract enforcement, facilitates economic development also presupposes the institutionalisation of certain norms or social values that promote market exchange, savings, and investment (Huntington, 2002). This is the context of the relationship between culture and economic behaviour.

\subsection{Cultural Infrastructure and Africa's Development}

That Africa has a rich cultural heritage is irrefutable. That there is a close relationship between a society's culture and attitudes of the people and economic development or the trajectory thereof is made eloquent by the giant strides of the Asian Tigers. To be sure, African culture is imbued with warmth, hospitality and sense of communal relations; it is built on optimism and resilience, even in the face of adversity; it thrives on collectivism based on communal effort; it is anchored on tribal politics, leadership and patronage. Historically, it is largely agrarian and bucolic; and it is secured on self-determination. It is said that civilisation began in Africa, precisely in Egypt. In fact, in the traditional African society, some of the egregious manipulative tendencies of the urban elite, such as corruption, lack of transparency and accountability, are very un-African. In a sense, the original architecture of African culture bore ingredients of competence, competitiveness, discipline, hard work, individual and communal trust and resilience.

Speaking of infrastructure, two distinct kinds are critical in sustaining economic development of a nation: physical infrastructure and cultural infrastructure. Investments in physical social development institutions such as education, power supply, healthcare, transport system, telecommunications, legal, security (police and armed forces), legislature and public sector agencies are classic examples of physical infrastructure. Sustained investments in physical infrastructure enhance a country's global competitiveness through the creation of its own unique competitive advantage. National competitiveness can obviously arise out of the aforementioned physical infrastructure. However, because physical infrastructure can be acquired from the market (that is, bought and sold on the basis of supply and demand), transplanted and replicated anywhere, their availability does not necessarily promise or sustain long-term competitive advantages. A nation needs to build a strong cultural infrastructure which will help create clear differentiating attributes.

The notion of cultural infrastructure connotes two things. First, it requires a strong cultural environment. Cultural environment provides the hospitable atmosphere in which human capacity development flourishes. It empowers citizens and foreign entrepreneurs alike through effective knowledge creation, communication and application. As earlier noted, the architecture of traditional African culture consists of industry, adroitness, communal effort and trustworthiness. When properly harnessed, these cultural features can stimulate competence, ingenuity, innovation and entrepreneurial competitiveness, discipline, trust and resilience in the workplace. These attributes are at the heart of national advantage.

Second and related, cultural environment does not evolve on its own nor is it a happenstance phenomenon. Rather, creating appropriate cultural atmosphere of the kind that supports socioeconomic development and economic growth is the result of deliberate government policies under strong political leadership. Governments at all levels have a responsibility for, and must focus on, enhancing factors of production. This entails massive investment in knowledge acquisition and improvement, essentially education at basic and post-basic levels, training and retraining, vocational and entrepreneurial skills acquisition. In addition, the architecture to support market economy must be available, accessible and inclusive, including banking facilities with credit availability. Access to social opportunities that arise from a market-driven economy should be the driving force behind all government policies. But the economic opportunities so created can only be accessed by citizens who have the ability to benefit thereof. The effectiveness of a market mechanism and the ability of a wider population of the citizenry to benefit from it - its inclusiveness or reach - are determined by the country's level of education as a proxy to the country's human capital and capabilities.

Just as the distribution of culture in the world reflects the distribution of power, so does its extinction or attenuation signify loss of influence. The erosion of the bonds of colonial rule following political independence in the 1950s and 1960s saw a gradual attenuation of colonial culture. The indigenisation of national cultures progressively swept away colonial hegemony with their cultures and civilisations, and in their place brought a rapid reassertion of indigenous mores, beliefs, languages, and institutions. The rapid disappearance of Western societies and civilisations and the growing power of indigenous cultures produced, at worst, powerful anti-Western civilisations, or gradual dismantling of the apparatuses of Western societies, at best. Ancient kingdoms with historically rooted traditions became the command power and new order of village or rural community life. The gains of colonial civilisation and cultures were lost and abandoned to the ignominy of ruthless, visionless and corrupt independent African leaders through several military interregnums. Emergent African leaders were soon to become the continent's worst post-colonial masters. It did not take long before post-colonial African rule assumed a new imperialist posture with nightmarish consequences in cultural, economic and political respects. 
The new imperialist leaders soon transformed African countries into a continent of great potentials and unfulfilled promises.

One statistic that eloquently captures the failed cultures and jaundiced civilisation of Africa is the socioeconomic development gap that now exists between Africa and South Korea and South East Asia. Yet, during the early years of the post-colonial era, the GDP of many African countries was at par with, if not better than, the Asian tigers. But sadly, Africa has dwindled and has been groaning with poverty, diseases, corruption, and inept leadership. By a 2013 account, South Korea's GDP is multiple times larger than most African countries' GDP. For example, South Korea is ranked $15^{\text {th }}$ in the current global list of countries by GDP (Nominal), with US $\$ 1,116,247$, while the closest African country, South Africa, is ranked $29^{\text {th }}$ with a distant GDP of US $\$ 408,074$ (before Nigeria's rebasing of GDP). What is responsible for the abysmal performance and failure of the African continent in comparative terms? How and where did the rain start beating us, African people? What explains this sad realism?

At the individual level, Africans are industrious, skilful, creative, responsible, competitive and resilient. These are essentially the moral grounds upon which productivity and civilisation flourish. They are the cultural values that underpin the prosperity of nation states. While it is indisputable that much of the individual achievements of the rich Africans are cocktailed with 'palace' corruption, patronage and manipulation (through state contracts and concessions), the individual wealth successes lead one to ask: Does the wealth of individual citizens agglomerate to the wealth of a nation?

\section{Policy Options}

\subsection{Adoption of the Clinical Economics Framework}

In order to break away from, and avoid many of the mistakes and pitfalls of the past, time has come for an auspicious adoption of a clinical economics approach (Sachs, 2005; 2011) as a new economic policy and development paradigm. This approach calls for six basic propositions as policy options. First, the clinical economics approach requires that national governments adopt a differential ideological basis to underpin policy formulation and development. This demands that governments undertake a thorough diagnosis of their developmental problems - a SWOT analysis - so as to contextualise their strengths and weaknesses. A clinical economics approach demands a focus in orientation in the pursuit of economic development. The approach must be clinically diagnostic in identifying and addressing critical factors that have facilitated or hampered economic growth of Africa.

Macroeconomic policies should diagnose the source and reasons for economic crises and seek ways to correct breakdowns in key sectors of the economy. This may entail a detailed analysis and an understanding of how the different parts of the economy and society fit together and interact with the world economy through trade, finance, and geopolitics. First, there should be an understanding of the people's beliefs, the country's social history, and the society's underlying values. All of these necessitate a broad and eclectic set of tools. Second, the ground for lasting economic solutions is watered by (a) the interplay of economics, politics, and the society's culture, and (b) bringing these components into a proper balance.

Second, the approach mandates a new interactivity necessary to harvest national and regional partnerships for IKS resource sharing and which supports research with cross-cutting themes and authorship that transcend national boundaries. African governments should show a stronger commitment to a better tomorrow, a better Africa, with a readiness to take risks and seek renewal of hope of their citizens. African leaders should rise to embrace a new frontier of human security-based socioeconomic development, driven by large investments in education (at all levels), healthcare services, innovation and entrepreneurship - to make greater contribution to fulfilling people's dreams of steady power supply, quality education, healthcare delivery system, efficient transport system, equality of life and justice, prosperity, and freedom for everyone, everywhere. The clinical economics approach identifies with cultural and economic security-based development paradigms, taking a holistic view of Africa's economic, social and political predicaments and challenges. This perspective enables policy makers, at national and regional levels, to diagnose some of the deeper maladies afflicting their societies and to correct past basic misdiagnoses that have afflicted and still afflict socioeconomic development (Herbert, 2014).

\subsection{Has Africa been moving in the wrong direction? Need for Remodelling the Options}

The observation by Shakespeare that, "the oft sight of means to do ill deeds makes deeds ill done" seems applicable to the intractable perverseness of African society. The modern African system is deficient, from government structures and policies to individual private lives. Economic insecurity in today's Africa is a compelling evidence of cultural insecurity. Why is it that things that work very well in other continents do not work in Africa? Why is Africa tottering when the rest of the world is advancing? 


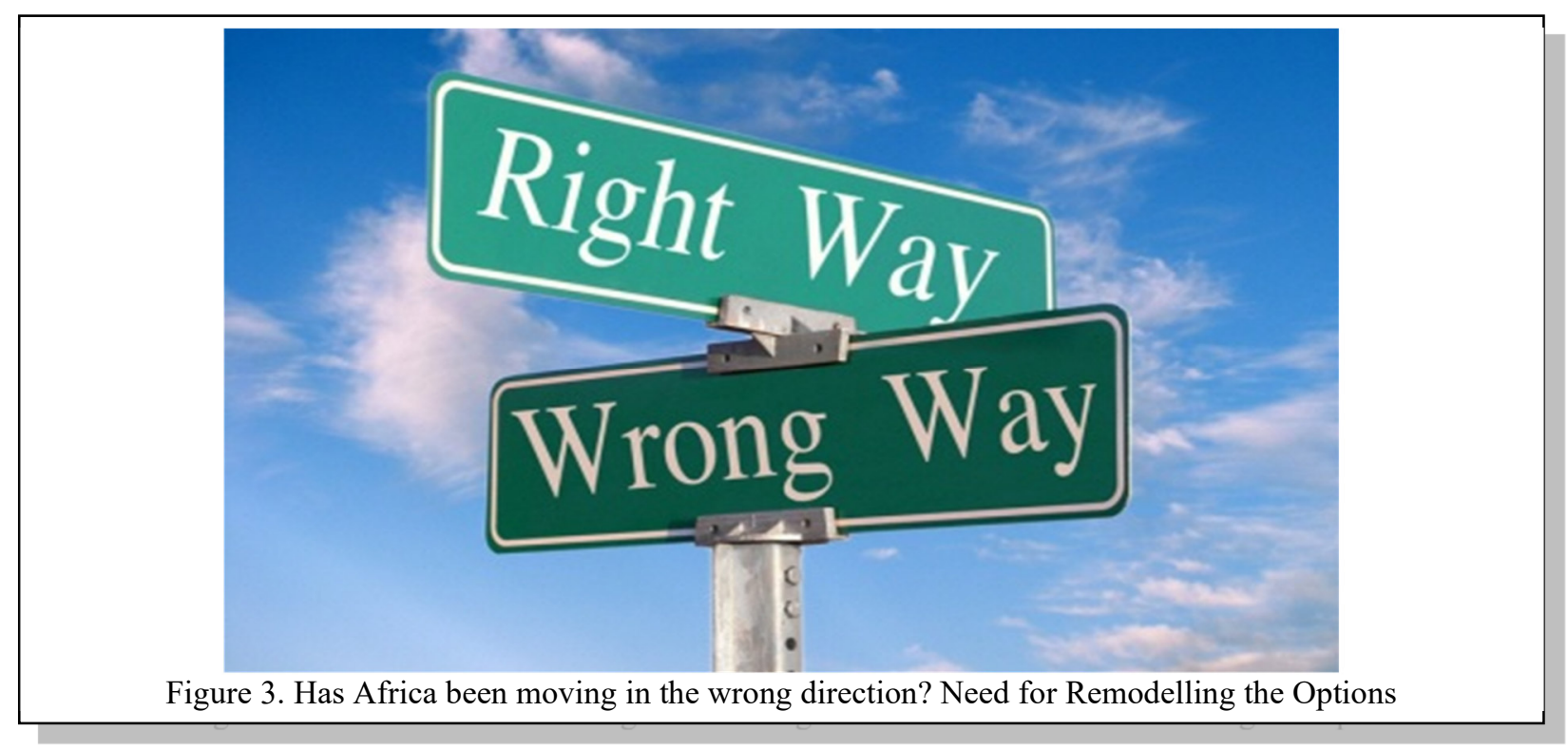

\subsection{Equivalent of Marshall Plan}

Third, Africa must consciously develop a comprehensive economic development plan (equivalent of a Marshall Plan) to ensure the region's economic stability and strategic security in the $21^{\text {st }}$ century. The road to Africa's recovery and prosperity is long, winding and tortuous. It probably needs financial aid on the scale of the Marshall Plan. Like the European economies after World War II, ethnic wars, extreme poverty, diseases, bad governance and all indices of human degradation and underdevelopment have ravaged Africa. Africa exhibits all the attributes of post-World War II Europe. Africa needs massive rebuilding of her devastated economies and regions. Africa needs a large-scale rescue programme whose goals should be (a) to rebuild her devastated regions, (b) build and modernise its infrastructure (electricity and transport system, education and healthcare systems, in particular), (c) remove trade barriers, (d) modernise her industries, (e) improve education and literacy rates, and (f) engender transparent and accountable governance in both public and private sectors. With faithful implementation, the rising levels of poverty and unemployment and associated social vices vis-à-vis growing population will be drastically reduced.

\subsection{Grand Strategy for Indo-China Relations}

With the growing influence of China and India in the economic and political affairs of Africa, there is need for a strategic reflection on the mistakes of the past with American and European jaundiced and one-sided partnerships. China is now the focus of great optimism as a powerful emerging nation that would be a showcase for industrialisation and globalisation. With studied retrospection, individual African countries and the continent as a whole would be wise to construct their newfound bonds with China and India, based on cultural and economic security. In this regard, this paper suggests, as the fourth option, the establishment of Council for Africa-China Relations (CACR) and the African Council for Cultural and Economic Relations (ACCER) to provide a regional mechanism to conduct foresight studies, evaluate national and continental economic and cultural relations, and develop the 'grand' strategies that would follow. The studies would look at the entire African system, such as the economy and its relationship to national, regional and continental security. The ACCER is another neglected but important policy agenda to engage Africa's economic and cultural security in the face of globalisation and its discontents. In sum, both the CACR and ACCER are imperatives that should be established at the regional level.

Governments all over the world often have cause to impose tariffs or ban certain items altogether. Imposition of tariffs or ban on importation of certain goods is part of a strategic impulse to promote national security. Such policies are aimed at guaranteeing self-sufficiency, saving foreign currencies, protecting domestic industries, generating employment, and enhancing economic growth and development. Achieving these goals requires strategic effort not only on a national level but also entails regional and continental cooperation. An important aspect of regional economic and trade agreements is to ensure inter-national cooperation in regional development. As the fifth option, it is hereby suggested that regional and Africa-wide cooperative efforts be enhanced to elicit unanimous position during the WTO rounds of talks and agreements. The strategy of syncretism or harnessing aspects of traditional cultures, beliefs or practices for essentially economic (managerial) ends was a major factor contributing to the success of industrialisation in Japan since the end of $19^{\text {th }}$ century (Dore, 1973) and in Hong Kong, Singapore, South Korea and Taiwan since the 1950s (Hamilton and Biggart, 1988; Clegg, 1990). While all these Asian nations have a relatively homogenous cultural milieu, African countries, by contrast, are multi-ethnic 
and multi-religious societies.

Sixth, since a large population of Africans live outside Africa, there has to be a concerted effort to create a homeward awareness of roots of African-Americans and the African diaspora. Such homeward historical journeys must be properly harnessed and structured on the basis of ancestral historicity. African-Americans are fascinated by their history and have a yearning for their past and their roots. If well-cultivated, such desires can open up exciting vistas of global cooperation and investment in the land of their fathers and forefathers. In addition, through constructive engagements of the African diaspora, Africa can elicit investment contribution to their motherland, just as the offshore Chinese and Indian communities, in terms of investment, remittances and social networking. The prayers, hope and the bond of Africans at home and in the diaspora, including African-Americans, are for a new Africa which we all can call our home; a flourishing continent that is devoid of bad governance, corrupt business practices, extreme poverty, diseases, ethnic tensions, wars and other social vices. With a renewed strategic focus, the seeds of a new Africa can grow from the imagination of exiled Africans. At the gateway to this dynamic and globalised $21^{\text {st }}$ century, Africa must build on a head start in transforming its peoples and societies by remodelling the options for culture and economic security in the continent.

\section{Concluding Remarks}

The foundation of Africa's strength must lie in its cultural and economic growth. In the long run, the welfare of African people will determine Africa's strength in the world; particularly, as national, regional and continental economies become increasingly integrated and inextricably linked to other economies. Africa's prosperity must serve as a wellspring for her power. Her cultural and economic strength will pay for her military, underwrite her diplomacy and development efforts, and serve as a leading source of her influence in the world.

Africa cannot afford to take cultural and economic security for granted nor can she take economic growth, stability, and prosperity for granted. The fact that Africa is endowed with natural resources should not blight her vision while other continents are all pursuing aggressive nationalistic and regional policies of economic development and growth. Africa cannot also pretend or presume that public order, security, economic and social progress, and prosperity come naturally. Instead, African governments need to realise that socioeconomic and political benefits are the consequences of relentless effort and attention from (a) effective and honest governments; (b) a private sector that is resolute to partner with governments all the way; (c) a public service that is determined to embrace reforms and changes in its modus operandi; and (d) a civil society that is willing to put country first and bear the inevitability of short-term pains for long-term future gains.

This should form the crux of our article of faith to guide our policies, if we are to succeed, to make it from poverty to prosperity. With a new impetus, Africa has an opportunity to embark on a new paradigm shift, as the continent seeks hope in the seemingly hopeless global economic and financial crisis, as the continent swims against the tide of imperatives of globalisation, and as the nations of the world grapple with one global crisis or the other, Africa must align herself with the rest of the world in a collective determination and policy drive to overcome the seemingly intractable challenges. Make no mistake: the era of self-delusion is gone. Africa must acknowledge her shortcomings, confront the challenges, and exploit the opportunities. This warrants a departure from the past.

If the roots of Africa's stunted development were series of poor policy decisions at both national and regional levels, the soil in which those roots were planted was an earth rotavated by corrupt leadership and bad governance. The choices African governments and their leaders make have a huge bearing on the development of strong cultural and economic security and the opportunities it provides for growth and development of the continent. Cultural and economic security is a dynamic phenomenon. Success in the global economy does not require a miracle or an elixir: it doesn't demand the world to provide special conditions to enable countries to prosper, in the form of trade or aid preference. Countries that grow their economies and develop fast are those whose leaders take sound and courageous decisions in the national interest. Paradoxically, Africa's greatest natural assets - Africa's youth, Africa's elite - far from being the fount, source of talent, and driver of socioeconomic development, are the continent's source of insecurity, instability, inept and corrupt leadership and bad governance.

This paper has encapsulated the challenges ahead and the apparent contradiction of Africa's culture with economic development and growth. Remodelling the options for cultural and economic security in Africa poses a rousing challenge to extant orthodoxy on African development. The solution to Africa's development is chiefly internal, and not the responsibility of development partners and donor agencies. The tendency of African leaders and governments to externalise their problems by playing the blame game is self-defeating. The new tools of economic development must be built on the foundation of culture and economic security. Africa risks being trapped in the quicksand of culture and economic insecurity, political malaise, infrastructure deficit, ethnic rivalry and tension, extreme poverty, and high unemployment unless it takes the bull by the horns now.

\section{References}

Australian Human Rights Commission (AHRC) (2011). Cultural safety and security: Tools to address lateral violence. Social Justice Report. 
Bessarab, D. (2000). Working with Aboriginal families: A cultural approach. In Weeks, W. (Ed.), Issues facing Australian families: Human services respond. Melbourne: Longman Australia.

Block, F. (1977). The Ruling Class Does Not Rule. Socialist Register, May-June.

Bozeman, A. B. (1975). Civilizations under stress. Virginia Quarterly Review, 51, Winter.

Brundtland Commission (1987). Our Common Future: The World Commission on Environment and Development. United Nations (UN): Oxford University Press.

Clegg, S. R. (1990). Modern Organizations. London: Sage.

Coffin, J. (2007). Rising to the Challenge in Aboriginal Health by Creating Cultural Security. Aboriginal \& Islander Health Worker Journal, 31(3), 22-24.

Coffin, J. (2008). Rising to the challenge in Aboriginal health by creating cultural security. Aboriginal and Islander Health Worker Journal, 31(3), 22 - 24.

Crouch, C. (1979). The State, Capital and Liberal Democracy. In Colin Crouch (ed.), State Economy and Contemporary Capitalism. New York: St. Martin's Press.

Dore, R. (1973). British Factory \& Japanese Factory. London: Allen and Unwin.

Drury, A. (2010). Reducing racism in Aboriginal health care in Australia: where does cultural education fit in? Australian and New Zealand Journal of Public Health, 34, S87 - S92.

Fernández, M.E. (1994). Gender and indigenous knowledge. Indigenous Knowledge \& Development Monitor 2 : 6-7.

Hamilton, G. G. \& Biggart, N. W. (1988). Market, Culture, and Authority: A Comparative Analysis of Management and Organisation in the Far East. American Journal of Sociology, 94, Supplement, S52-94.

Herbert, W. E. (2011). State Capacity and the Politics of Economic Reform in Nigeria: Some Critical Issues. Journal of Business and Financial Studies. 2(2), 35-58.

Herbert, W. E. (2012). African Cultures and Africa's Economic Development. Journal of African Culture and International Understanding (A UNESCO Quarterly Publication), 1(1), 5-12.

Herbert, W. E. (2014). Culture and Economic Security in Africa: Remodelling the Options. Policy Brief. Institute of African Culture and International Understanding, No. 3, July-September.

Huntington, S. P. (2002). The Clash of Civilisations and the Remaking of Word Order. London: Simon \& Schuster UK Ltd.

Lalonde, A. (1991). African Indigenous Knowledge and Its Relevance to Environment and Development Activities. Presented for The Common Property Conference - Sept. 26-29, Winnipeg, Manitoba (Held by the International Association for the Study of Common Property (IASCP).

Maslow, A. H. (1943). A Theory of Human Motivation. Psychological Review, 50(4): 370-96. Retrieved from http://psychclassics.yorku.ca/Maslow/motivation.htm

Maslow, A. H. (1954). Motivation and Personality. New York: Harper. ISBN0-06-041987-3.

Nemeth, E. (2013). "Working towards a definition for Cultural Security". Accessed via the blog:erik.nemeth@culturalsecurity.net

Sachs, J. (2005). The End of Poverty: How we can make it happen in our lifetime. London: Penguin Books Ltd.

Sachs, J. (2011). The Price of Civilisation: Reawakening American Virtue and Prosperity. New York: Random House.

Senanayake, S.G.J.N. (2006). Indigenous Knowledge as a Key to Sustainable Development. The Journal of Agricultural Sciences, 2(1), 87-94. DOI: 10.4038/jas.v2i1.8117.

Szymanski, A. (1978). The Capitalist State and the Politics of Class. Cambridge, Mass.: Winthrop Publishers.

\section{Author's Biodata}

Wilson E. HERBERT is a Professor of Accounting and Financial Management in the Faculty of Management Sciences, Federal University, Otuoke. He holds a Master's degree in International Financial Management and a $\mathrm{PhD}$ (International Investment) from the University of Glasgow (1992). He is distinguished as the first Black African Professor of Accounting \& Finance in any British or European University. He was a Professor and Head of Financial Studies, University of Derby Business School, UK. He was later invited by the Federal Government of Nigeria for the operational takeoff of the Nigerian Education Bank (a Federal Government-owned educational development bank). He later became the bank's MD/CEO. He had been a Visiting Professor at the National Universities Commission, Head of Department of Accounting and Finance, Dean of Faculty of Management Sciences and Director of Academic Planning in different universities. He is a CertifiedFraudExaminer, Certified Forensic Accountant and a Fellow of several academic and professional bodies. He has over 150 publications in international journals. He has supervised/externally examined over $25 \mathrm{PhDs}$ in Accounting and Finance, a good number of whom are already Professors in the subject. His research interest is on forensic accounting and fraud examination, financial management and corporate governance. 